\title{
INVESTIGATING THE RECESSION PROCESS OF COMPLEX SOFT CLIFF COASTS: AN ISLE OF WIGHT CASE STUDY
}

\author{
Natasha Carpenter ${ }^{1}$, Caroline Stuiver ${ }^{1}$, Robert J. Nicholls ${ }^{1}$, William Powrie ${ }^{1}$ and Mike \\ Walkden ${ }^{2}$
}

\begin{abstract}
Understanding future retreat rates of soft rock cliffs is important for a range of coastal management activities, particularly when considering the impacts of climate change. One key method is process-based numerical modeling. However, this technique is still in its early stages and consequently the process of cliff recession is typically oversimplified. This paper reviews the application of the SCAPE (Soft Cliff and Platform Erosion Model) to a varied geological frontage on the south west coast of the Isle of Wight. Evaluation of the 2D model has been undertaken through validation of the output model profiles compared with measured and field data observations. The results have identified the importance of vertical variations in rock strength within the cliff system, which has a strong influence on recession rates, cliff morphology and the development of emergent features. Evaluation of the model has also highlighted the importance of translating cliff base retreat into an appropriate cliff top position, which defines the extent of the erosion hazards, and hence is of more practical use (e.g., land-use planning). This requires more consideration of the role of terrestrial processes within the cliff recession process.
\end{abstract}

Keywords: Cliff erosion, process-based modeling, predicting retreat, geomorphology

\subsection{INTRODUCTION}

\subsection{Global Perspective and Context}

Soft rock cliffs cover approximately $12 \%$ of the European coastline (Eurosion, 2004) and are widespread globally. They are defined by Pye and French (1993) as including "lithologies of any geological age which are poorly consolidated or cemented, including; glacial till, outwash deposits, friable sands and weakly consolidated clays and shales." They may also include areas of variable lithology, for example limestones or sandstones overlying clays are also included where failure of soft lithology at the base of the cliff leads to failure.

Soft cliffs are an important resource due to their physical, biological and earth science conservation value, which is related to their highly erosive nature. They create geomorphically diverse coastlines owing to the complex interactions between lithology, geological structure and inland relief, combined with the applied forces of marine and terrestrial processes (Lee and Clark, 2002). As they erode, they release sediment to the coastal and marine system which contributes to downdrift beach volumes. However, their rapid rates of erosion (in excess of $1 \mathrm{ma}^{-1}$ ) create worldwide problems associated with the sustainability of coastal settlements including in the USA, Canada, Japan, Russia, Denmark, Germany and the UK (Sunamura, 1992).

An understanding of future recession rates is required to inform a range of coastal management activities including; economic appraisal of coastal defenses, determining managed realignments and calculating sediment budgets (Hall et al., 2002). This is heightened by the need for more adaptive and sustainable strategies considering the substantial financial commitments associated with the provision of coastal defences and slope stabilisation works, which will face increasing pressure as we respond to the impacts of climate change (Linham and Nicholls, 2010). Therefore, one of the greatest challenges facing coastal engineers is to enhance our understanding of the soft cliff recession process, particularly considering potential variations to the system as a result of changing environmental and climatic conditions (Brown et al., 2006).

\subsection{Problem Statement}

There are five key techniques available to predict future rates of retreat; 1) historical extrapolation; 2) expert judgement; 3) empirical methods; 4) probabilistic methods; and, 5) process-based geomorphic modeling. Despite this range, a UK Government review stressed the need to further develop prediction methods (Lee, 2002), which is highlighted by two key limitations:

- Techniques are frequently related to historical projections. When considering the impacts of climate change or potential changes in the cliff system (e.g. variations in cliff height or composition over time), past conditions are no longer representative of the future and subsequently do not provide an accurate basis for prediction.

${ }^{1}$ Faculty of Engineering and the Environment, University of Southampton, Highfield Campus, Southampton, Hampshire, SO17 1BJ, UK

${ }^{2}$ Royal Haskoning, Stratus House, Emperor Way, Exeter, EX1 3QS, UK 
- Coastal processes are commonly considered to be the main driver of recession and subsequently the in-situ terrestrial processes also influencing the system are commonly omitted or over simplified.

The latter is particularly limiting for higher or more complex cliff systems as interactions with the terrestrial system become stronger in these instances. For example, Quinn et al (2010) noted for the Holderness coast (UK) that cliffs in excess of $7 \mathrm{~m}$ are more influenced by structural failures and mass movements as opposed to marine processes. Furthermore, more complex cliffs comprise of a series of interacting sub-systems resulting in dynamic feedback mechanisms between the cliff top and toe. Overall, this emphasizes the importance of assessing the combined response of both erosional and depositional environments if future rates of retreat are to be accurately understood (Trenhaile, 2004, Dickson et al., 2007).

Considering these issues we can recognize the need for a more integrated understanding of cliff recession and how the system may respond to changing climatic and environmental conditions (Brooks and Spencer, 2012). In response, the key method is process-based geomorphic numerical modeling, as it enables process interactions between a range of parameters in the cliff system to be represented and it can also simulate changing conditions (Hall et al., 2002).

A range of models are available including Kamphuis (1987), Meadowcroft et al (1999), Walkden \& Hall (2005) and Trenhaile (2009). However, the dynamic nature of the cliff recession process has, until recently, inhibited their development (Walkden and Dickson, 2008). Existing models are criticized for the generalized manner in which they treat cliff behavior (Trenhaile, 2009). This relates back to the limitations highlighted for more traditional methods; in that many models currently approach the system from a coastal perspective, failing to consider the episodic and stochastic nature of cliff top processes which are more difficult to describe in numerical terms (Hall et al., 2002). However, considering the merits of process-based modeling (in terms of understanding the cliff system, its range of feedback mechanisms and responses to changing conditions), there is an opportunity to develop a more integrated model of complex soft cliff recession.

\subsection{PREDICTION OF CLIFF RECESSION}

\subsection{The SCAPE Model}

Following a critical appraisal of the range of existing, process-based models, the SCAPE (Soft Cliff and Platform Erosion) model developed by Walkden and Hall (2005) has been selected as a basis for development. The model is a coastal engineering tool designed to determine the emergence and retreat of soft rock shore profiles in the mesoscale (a period of 10-100 years). Predictions over this timescale are enabled by representation of the cliff system within a reduced complexity model, where only the dominant parameters and processes are modeled as outlined in Figure 1.

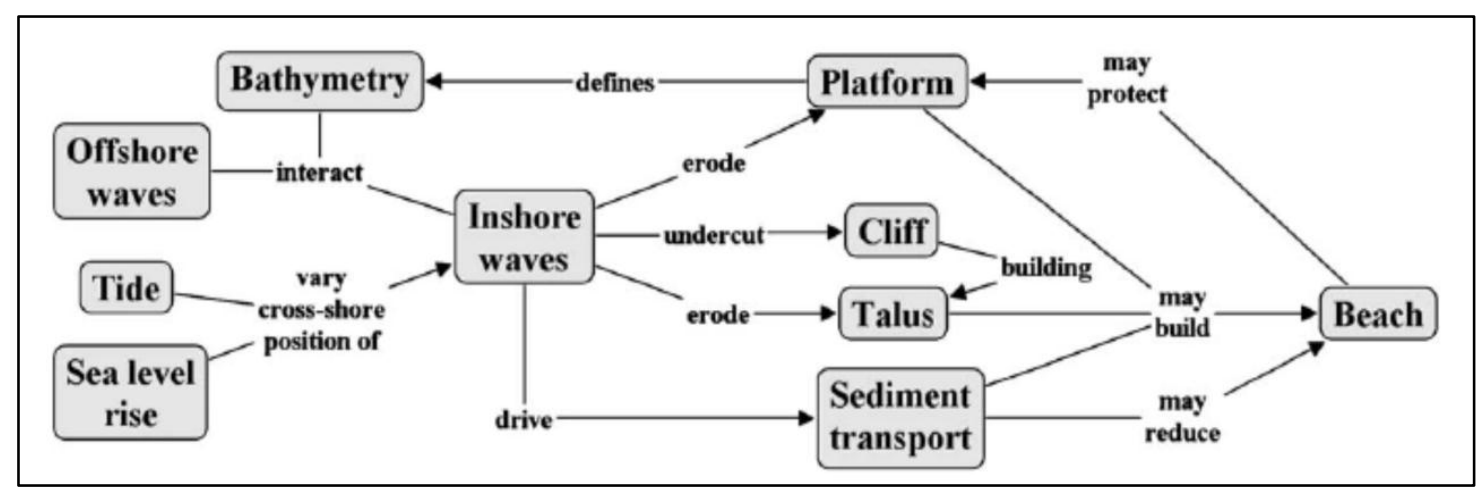

Figure 1. Outline of interactions considered within SCAPE (Walkden \& Hall, 2005).

To outline some of the governing principles of the 2D SCAPE model:

1. Wave transformation from nearshore points (including refraction, diffraction and shoaling) are described using linear wave theory (Kamphuis, 2000).

2. The beach is represented as a finite surficial layer resting on top of the shore platform. It is assumed to have an unvarying profile consisting of a flat berm to the limit of wave run-up fronted by a beach following the Bruun profile (Bruun, 1954). It is assumed that losses to the system occur 
through sediment transport; therefore there are no offshore losses of beach building material whilst fines are considered to be lost from the system.

3. Shore platform and cliff toe erosion are computed using an erosion shape function, within which the erosion rate is based upon an expression derived by Kamphuis (1987). The shape function is a dimensionless distribution of soft rock erosion under a breaking wave field which has been derived from the results of Skafel (1995). The latter work published the distributions of the erosion rate that resulted from physical model experiments in a wave tank with pseudo random waves shoaling and breaking over a glacial till shore.

4. Cliff failure and delivery of talus material to the beach is described by a simple module which treats the cliff as a block of material which shears after every ten erosion 'events' to maintain a vertical cliff face. All of the eroded material adds to the volume of the talus and a proportion of this contributes towards beach volume, as determined by the estimated percentage of 'beach building' material present.

In summary, the model simulates a comprehensive coastal system (for further detail the reader is directed to Walkden and Hall (2005), Walkden and Dickson (2008) and Walkden and Hall (2011)). This is based on the mesoscale assumption that upper cliff processes are only of relevance for the debris material provided to the cliff toe and beach. Furthermore, it should be noted, the roles of terrestrial and sub-aerial processes within the model are limited to a single calibration parameter for rock strength, which is considered to be homogenous in the cross-shore.

These assumptions have been sufficient to validate and verify the SCAPE at a number of sites in the UK including the Naze, Essex (Walkden and Hall, 2005) and north east Norfolk (Walkden and Dickson, 2008). However, such sites are relatively simple to model (with respect to the cliff system). For example, the Norfolk study frontage comprises of a gently curving $50 \mathrm{~km}$ coastline. The cliffs predominantly consist of glacial till and are relatively continuous simple cliffs which are characteristically steep and therefore highly responsive to basal marine erosion. However, it can be noted that this study site is more complex in terms of historic and future coastal intervention works.

\subsection{Model Application to Study Frontage}

In contrast to the previous SCAPE model applications, it is currently being applied to a more complex but natural cliff system on the south west coast of the Isle of Wight, UK (Figure 2). The area has been selected considering the:

- Varied soft rock lithology of the site which includes varying strength and composition, and its distinct structural geology;

- Diverse geomorphology of the frontage which includes a series of headlands and a range of cliff failure mechanisms;

- High long-term rates of cliff retreat combined with coastal management issues (described below);

- Natural character of the frontage, which has not been influenced by coastal engineering structures thus providing a clear picture of natural fluctuations in cliff retreat over time; and

- Data availability for the frontage.

Location and History The study frontage extends approximately $17 \mathrm{~km}$ across the south west coast of the Island from Compton Bay to Chale, as outlined in Figure 2. The boundaries have been selected considering the geological constraints of the chalk to the west and the Blackgang Chine Landslide to the east (which would be inappropriate to model with SCAPE as the landslide is strongly controlled by geotechnical processes). The cliffs within the frontage are typically $30 \mathrm{~m}$ high with some local variation from approximately $10 \mathrm{~m}$ in the north east to in excess of $50 \mathrm{~m}$ at Chale. Their morphology varies spatially, reflecting the differing combinations of controlling factors which highlights the complexity of the frontage.

The shore is unprotected and is covered by a long term policy of 'No Active Intervention' (NAI) within the Island's Shoreline Management Plan (SMP, (Isle of Wight Council and Haskoning, 1997)). This is predominantly owing to the areas environmental and landscape importance (as reflected by conservation designations at the site including; Compton Chine to Steephill Cove Site of Special Scientific Interest, World Heritage Coast and Area of Outstanding Natural Beauty). The eroding cliffs are also a source of sediment to downdrift beaches. The policy of NAI is further supported by the lack of feasibility and economic justification for localized intervention works (Isle of Wight Council and Royal Haskoning, 2010). 
The cliffs are retreating at a steady rate of $0.2-0.5 \mathrm{~m} / \mathrm{yr}$ as supported by a variety of studies (SCOPAC, 2004), which poses a range of coastal management issues. There are a number of communities and isolated properties which have been lost along the frontage and the A3055 Military Road (which is key infrastructure) had to be realigned in the 1930's at Compton, requiring substantial investment. Two significant stretches of the road are currently recognized as under threat within the study frontage, with one lane closure in progress for a short section owing to recent landslide activity (Isle of Wight Council, 2010). This highlights the need for long-term land-use and coastal planning, which is reinforced by the unknown future impacts of climate change.

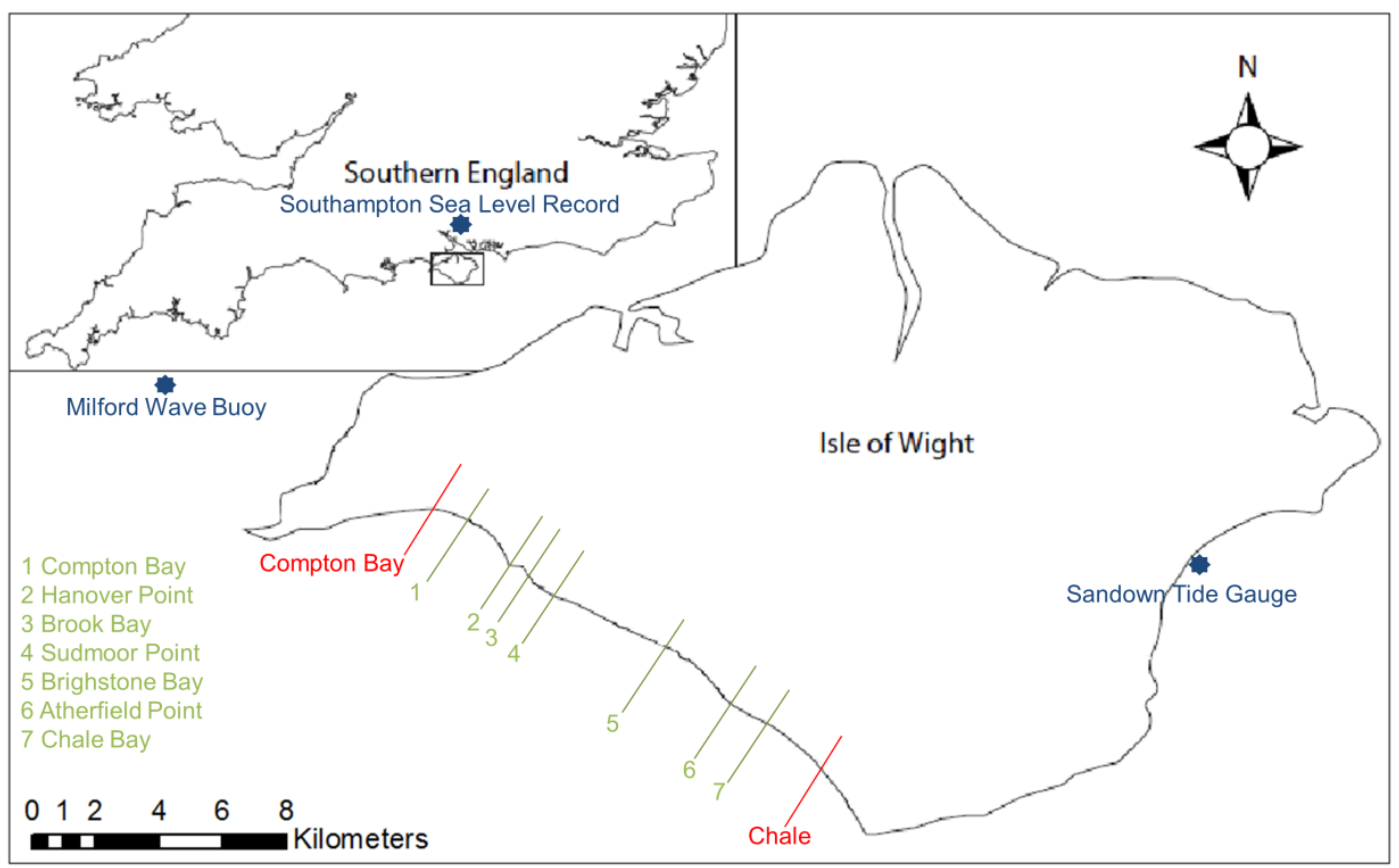

Figure 2. Map outlining the study frontage, 2D model transects and sites of key data sources (adapted from Leyland (2009)).

Physical Characteristics The study frontage consists of the Wealden and Lower Greensand series of the Lower Cretaceous (approximately 112- 120 million years old), the latter of which is overlain by Pleistocene deposits. The rising sea levels of the early Holocene reoccupied the former degraded cliffs, renewing erosion of the soft geology to form the rapidly retreating coastline seen today (Leyland and Darby, 2008). As the coast has retreated it has produced a shore platform which extends approximately $4 \mathrm{~km}$ seaward (SCOPAC, 2004). The frontage comprises of four bays (Compton, Brook, Brighstone and Chale) separated by three discrete headlands (Hanover, Sudmoor and Atherfield respectively). These have developed due to local occurrences of harder lithologic units outcropping in the inter-tidal zone.

The cliffs along the study frontage are varied, typically exhibiting simple landslide morphology. However, local transitions to complex landslides and rockfall dominated forms do exist, particularly towards the south east. These more complex landslide behaviors are characterized by periodic high magnitude cliff top events (Isle of Wight Council and Royal Haskoning, 2010).

Hydrodynamic Climate The study frontage has oceanic fetches in excess of $4,000 \mathrm{~km}$ across the Atlantic, along with shorter fetches across the English Channel. It is exposed to significant swell wave activity, as well as to energetic locally-generated wind waves. Figure 3 shows wave data from the Milford Wave Buoy, located to the north west of the study frontage (Figure 2). The predominant direction is from the south-west with a five year significant wave height of $3.93 \mathrm{~m}$ (Channel Coastal Observatory, 2010).

The tidal characteristics vary alongshore as the site is close to a degenerate amphidromic point. The tide has been interpolated to represent the study frontage, as outlined in Table 1. The tidal range is small so that wave energy is concentrated over a limited vertical range. However, the shallow nearshore and shore platform causes some dissipation and breaking of large waves some distance offshore. 


\begin{tabular}{|l|c|c|}
\hline \multicolumn{3}{|c|}{ Table 1. Typical Tidal Characteristics of the Study Frontage } \\
\hline Tide & Abbreviation & Level (mOD) \\
\hline Mean High Water Spring & MHWS & 1.12 \\
Mean High Water Neap & MHWN & 0.62 \\
Mean Sea Level & MSL & 0.04 \\
Mean Low Water Neap & MLWN & -0.54 \\
Mean Low Water Spring & MLWS & -1.24 \\
\hline
\end{tabular}

Beaches along the study frontage typically rest as a veneer of sediment on top of the underlying shore platform. The beaches are of low volume and consequently provide limited protection to the cliff toe and shore platform. They can be divided into three units based on abrupt changes in median grain size. 1) From the northern boundary of the study frontage to the south of Sudmoor Point the beach displays a dissipative form and is composed of medium to fine grained sand. 2) From the south of Sudmoor Point there is an increase in the backshore grain size creating a pebble beach which takes on a reflective form until Atherfield Point. 3) At Atherfield Point the grain size decreases to coarse sand, gradually increasing to the south becoming pebbles again by the southern boundary of the study frontage.

The cliffs deliver large quantities of sand and clay sediment. However, most material is believed to be removed offshore in suspension. Net wave driven sediment motion in the area is from north west to south east. The offshore to onshore supply of sediment by wave-induced or tidal current may account for a proportion of the beach. However, knowledge of nearshore sediments and possible pathways of transfer to littoral transport is limited (Brampton et al., 1998) and the field characteristics of the cliff/beach system is being further investigated. Just outside the boundaries of the study frontage, the Needles and St Catherine's Point are current-swept bedrock surfaces which imply limited supply potential.

\subsection{Model Set-Up}

A series of seven 2D SCAPE model profiles were set-up to assess the models ability to replicate the key processes occurring at the main headlands and bays along the frontage, as outlined in Figure 2. The model profiles were constructed to represent the state of the study frontage in 2008, considering its development over the preceding 142 year period (from 1866 when the first accurate map was produced). Table 2 summarizes the preliminary input parameters which have been grouped by purpose.

\begin{tabular}{|l|l|l|l|}
\hline \multicolumn{3}{|l|}{ Table 2. Input Parameters for the Study Frontage (sources explained in the text) } \\
\hline Purpose & Preliminary Inputs & Units & Value Range \\
\hline Profile evolution & Baseline angle & Degrees & $298-328$ \\
& Offshore contour depth & $\mathrm{m}$ & 8.7 \\
& Offshore contour angle & Degrees & $303-330$ \\
& Wave height & $\mathrm{m}$ & Variable with time \\
& Wave period & $\mathrm{S}$ & Variable with time \\
& Initial beach volume & $\mathrm{m}^{3} / \mathrm{m}$ & $1.5-3.5$ \\
& Run-up limit & $\mathrm{m}$ & 2.07 \\
\hline Beach slope & Bruun constant & - & $0.1-0.2$ \\
\hline $\begin{array}{l}\text { Cross-shore distributions of } \\
\text { sediment transport and } \\
\text { erosion }\end{array}$ & Tidal amplitude & $\mathrm{m}$ & Variable with time \\
\hline $\begin{array}{l}\text { For the calculation of beach } \\
\text { sediment volumes released } \\
\text { from the cliff }\end{array}$ & Rate of sea-level rise & $\mathrm{mm} / \mathrm{yr}$ & 1.4 (historic) \\
\hline Calibration variable & Cliff top elevation & $\mathrm{m}$ & $14.5-34.6$ \\
\hline
\end{tabular}

Hourly wave data including significant wave height, period and direction were taken from the Milford Wave Buoy records for the period of $1996-2011$. These waves represent conditions to the north west of the study frontage (Latitude: $50^{\circ} 42.75^{\prime} \mathrm{N}$, Longitude: $001^{\circ} 36.91^{\prime} \mathrm{W}$ ) where the water depth is approximately 10m CD. Tide level data recorded at 15 minute intervals from $2006-2011$ were available for Sandown Pier Tide Gauge $12 \mathrm{~km}$ to the north east of the study frontage (Latitude: $50^{\circ} 39.0666^{\prime} \mathrm{N}$, Longitude: $01^{\circ} 9.18960^{\prime} \mathrm{W}$ ). This data was interpolated to represent the study frontage and then filtered to obtain the high tide values to be used as the model input. The wave and tide files were recycled as they were shorter than the modeling period. No attempt has currently been made to include extremes not represented in the records. Historic sea-level rise was based on Haigh et al (2011) for Southampton. The data sources are highlighted on Figure 2. 
The slope and curve of the beach for each 2D profile was defined by setting the Beach Bruun Constant $(a)$. This value was determined considering the median grain size of sediment at the profile derived from field data.

Cliff heights and shore positions were extracted from LiDAR data available for the study frontage from the Channel Coastal Observatory (CCO) for the year 2007. The beach grade material within the cliff was determined considering field estimates ${ }^{3}$ for each main geological group and formation present along the frontage (as outlined in Table 3). This has been combined with knowledge of the geological characteristics of each profile considering geological mapping of the frontage, which is further discussed in Figure 4 below.

\begin{tabular}{|c|c|c|c|c|}
\hline Group & Formation & Member & Lithology & $\begin{array}{l}\text { Estimated } \\
\text { Beach } \\
\text { Grade } \\
\text { Material } \\
(\%)\end{array}$ \\
\hline & $\begin{array}{l}\text { River } \\
\text { Terrace } \\
\text { Deposits }\end{array}$ & $\begin{array}{l}\text { Brickearth } \\
\text { Valley Gravel }\end{array}$ & $\begin{array}{l}\text { Windblown silt } \\
\text { Coarse angular flint gravel in a sandy } \\
\text { matrix }\end{array}$ & $\begin{array}{c}0 \\
90\end{array}$ \\
\hline \multirow[t]{2}{*}{$\begin{array}{l}\text { Lower } \\
\text { Cretaceous }\end{array}$} & $\begin{array}{l}\text { Ferruginous } \\
\text { Sands }\end{array}$ & A range of 11 members & $\begin{array}{l}\text { Red Sandstone } \\
\text { Grey Sandstone }\end{array}$ & $\begin{array}{l}60 \\
50\end{array}$ \\
\hline & $\begin{array}{l}\text { Atherfield } \\
\text { Clay }\end{array}$ & $\begin{array}{l}\text { Upper Lobster Beds } \\
\text { Crackers } \\
\text { Lower Lobster Beds } \\
\text { Chale Clay } \\
\text { Perna Bed }\end{array}$ & $\begin{array}{l}\text { Alternating muds and sandy silts } \\
\text { Fine sand with concretions } \\
\text { Clay } \\
\text { Clay } \\
\text { Calcareous sandstone and sandy clay }\end{array}$ & $\begin{array}{c}0 \\
10 \\
0 \\
0 \\
20\end{array}$ \\
\hline \multirow[t]{2}{*}{$\begin{array}{l}\text { Wealden } \\
\text { Beds }\end{array}$} & Vectis Shale & $\begin{array}{l}\text { Shepherd's Chine } \\
\text { Barnes High } \\
\text { Cowleaze Chine }\end{array}$ & $\begin{array}{l}\text { Inter-bedded Shale and Silt } \\
\text { Channel Sandstone } \\
\text { Inter-bedded Shale and Silt }\end{array}$ & $\begin{array}{c}50 \\
0 \\
50\end{array}$ \\
\hline & $\begin{array}{l}\text { Wessex } \\
\text { Marls }\end{array}$ & & $\begin{array}{l}\text { Variegated marl inter-bedded with } \\
\text { channel sandstones }\end{array}$ & $0-10$ \\
\hline
\end{tabular}

\subsection{Model Development}

There are several stages of development of the model. A profile is initially allowed to emerge from a vertical profile and to develop to dynamic equilibrium using the $2 \mathrm{D}$ model. Upon profile development, the material resistance calibration parameter can be altered to establish one that provides approximately correct average rates of retreat over a known historic period. Since confidence in the model cannot be based on the average recession rate (which has been fixed by the calibration process), validation is based on examination of emergent model features and compared to measured data.

Upon calibration and validation of the 2D profile, a quasi-3D model of the frontage can be developed. The latter is coupled with a one-line beach module, enabling interaction between a series of $2 \mathrm{D}$ profiles.

\subsection{PRELIMINARY RESULTS}

The results presented within this paper focus on the application of the 2D SCAPE model to the 7 sites selected along the IoW frontage highlighted in Figure 2.

\subsection{Profile emergence}

Figure 3 illustrates the emergence of a representative 2D SCAPE profile from an initial vertical cliff based on the prevailing site conditions. Figure 3a shows profile development every 100 years (from right to left, year $0-500)$. Owing to the steepness of the initial cliff, high rates of retreat can be observed between this feature and year 100. The emergence of the junction between the shore platform and cliff toe at approximately MHWS can also be observed. Figure $3 \mathrm{~b}$ shows the further development of the profile every 1,000 years (year 1,000-5,000). The Figure shows the shore platform widening over time and profile surface irregularity decreasing as previously highlighted by Walkden \& Hall (2005).

\footnotetext{
${ }^{3}$ Estimates will be updated with laboratory results in future models.
} 


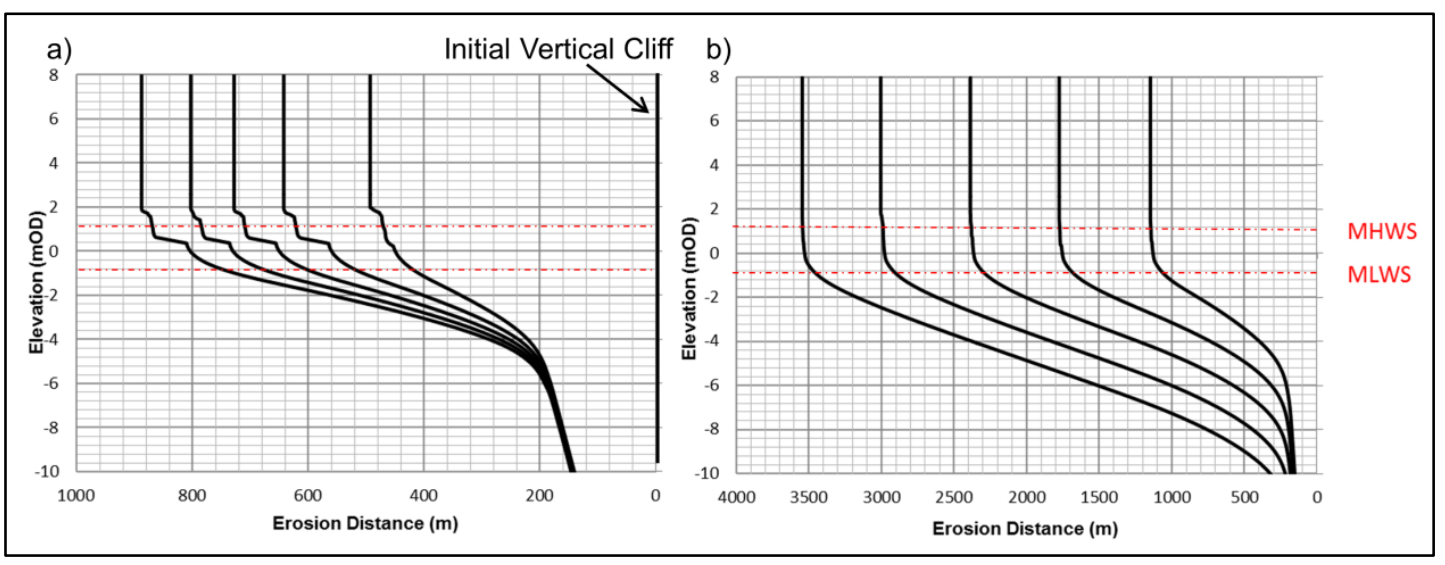

Figure 3. Emergence of the Shore Platform and Cliff Toe a) profile every 100 years (year $0-500$ ) b) profile every 1,000 years (year $1,000-5,000$ )

\subsection{Model Calibration}

Table 4 provides a summary of the calibration process. Historic rates for calibration were determined using the Digital Shoreline Analysis System (DSAS, (Thieler et al., 2009)) for a series of historic maps and aerial photographs available over the modelled period. Table 4 also provides a comparison of the required rock strength parameter and how this compares to site observations. The latter has been determined using a visual appraisal of coherence for soft rock lithology based on Soares (1993) considering the main geological groups present within each profile. Within the classification coherent rocks are distinguished as those hard to break by hammer impact (compressive strength of approximately 20MPa) through to non-coherent rocks, described as those which disintegrate easily under finger pressure $(<0.5 \mathrm{Mpa})$.

\begin{tabular}{|c|c|c|c|c|}
\hline \multirow[t]{2}{*}{ Location } & \multicolumn{2}{|c|}{ Historic Recession Rate } & \multicolumn{2}{|c|}{ Rock Strength } \\
\hline & $\begin{array}{c}\text { Measured } \\
(\mathrm{m} / \mathrm{yr})\end{array}$ & $\begin{array}{c}\text { Modeled } \\
(\mathrm{m} / \mathrm{yr})\end{array}$ & $\begin{array}{l}\text { Cliff Visual Appraisal } \\
\text { (coherent (1) - non (4)) }\end{array}$ & $\begin{array}{l}\text { Calibration Parameter } \\
\left(\mathrm{m}^{9 / 4} \mathrm{~s}^{3 / 2}\right)\end{array}$ \\
\hline Compton Bay & 0.49 & 0.51 & 2 & $26 \times 10^{6}$ \\
\hline Hanover Point & 0.71 & 0.69 & 3 & $16 \times 10^{6}$ \\
\hline Brook Bay & 0.52 & 0.52 & $2-3$ & $25 \times 10^{6}$ \\
\hline Sudmoor Point & 0.41 & 0.43 & 2 & $32 \times 10^{6}$ \\
\hline Brightstone Bay & 0.68 & 0.68 & $2-3$ & $15 \times 10^{6}$ \\
\hline Atherfield Point & 0.76 & 0.78 & 2 (dry) -4 (wet) & $14 \times 10^{6}$ \\
\hline Chale Bay & 0.43 & 0.44 & $1-3$ & $31 \times 10^{6}$ \\
\hline
\end{tabular}

A qualitative link between the calibration parameter and site observations of coherence can be identified. However, it can be noted that the calibration parameter is generalized across the entire profile and therefore does not reflect variations in geological strength, as demonstrated by the geological mapping provided in Figure 4. For example, at Sudmoor Point the geological cross section shows coherent sandstone overlain by intermediately coherent Wessex Marl and topped by a thin of layer of less coherent Brick Earth. These geological strata each have varying levels of coherence owing to their varying lithology (as indicated by Table 3), but this is not reflected within the single prescribed value of the SCAPE rock strength parameter. 


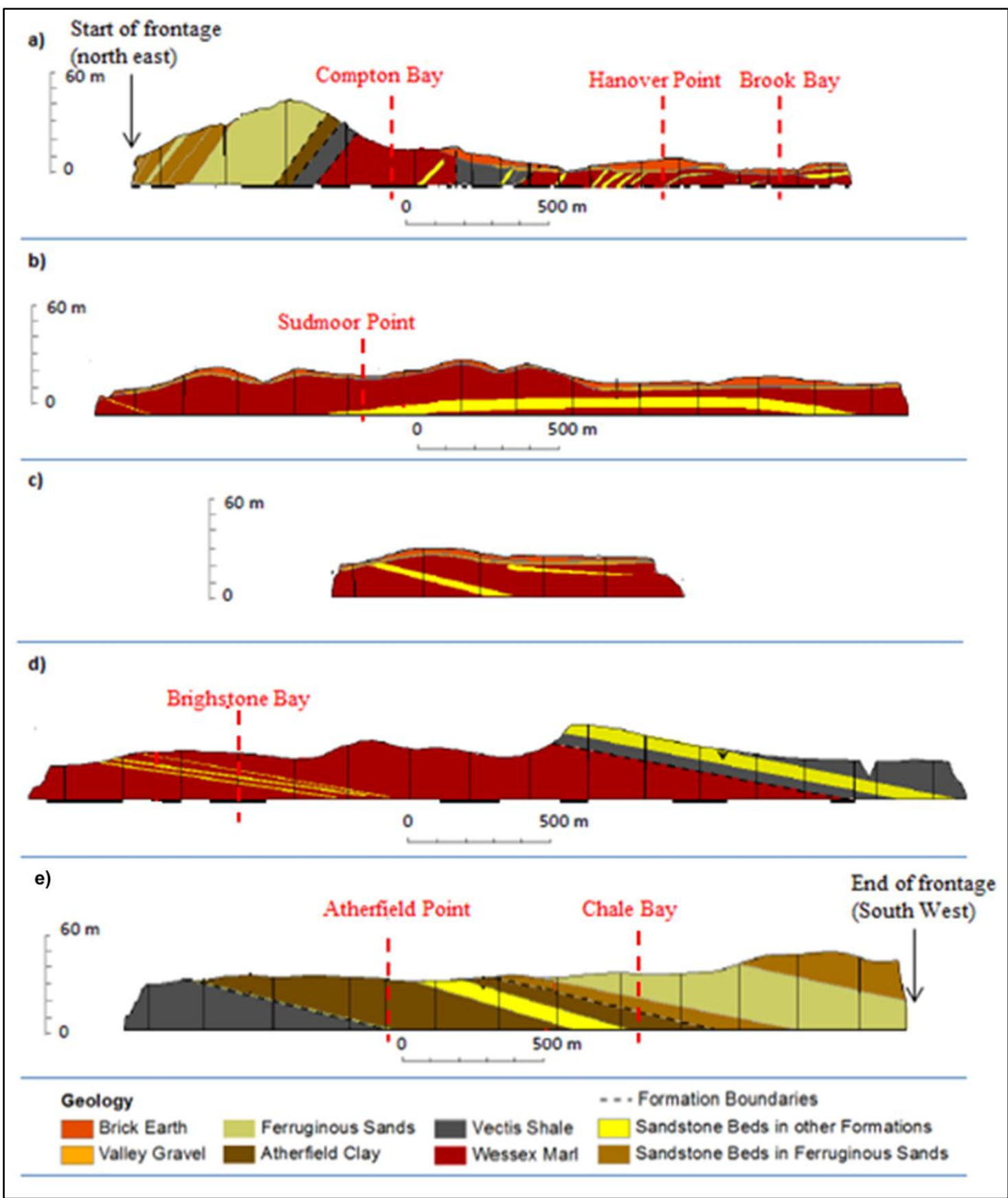

Figure 4. Geological Mapping of the study frontage from the north east (a) to the south west (e) highlighting the 2D profiles

\subsection{Model Validation}

Upon calibration the model was validated considering the shapes of the modeled shore profiles in comparison to extracted LiDAR data for the study frontage and the depth of the offshore contour compared to the distance offshore.

Figure 5 outlines the model profiles compared to measured data from 2007 (which corresponds to the penultimate year of the model validation period). The modeled profiles are generally slightly lower compared to the data and do not contain as much cross-shore detail. However, they are sufficient to indicate that the principal shore erosion processes have been adequately represented. Considering that the same wave and tide data is used to drive each of the model simulations, the variation in modeled results can be attributed to the varying input parameters at each site. For example, the profiles south of Sudmoor Point have more complexity owing to the higher cliffs and higher beach volumes. 


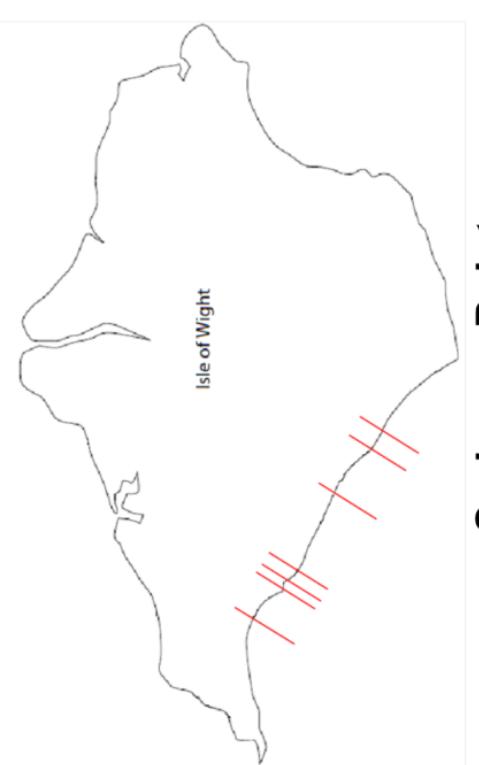

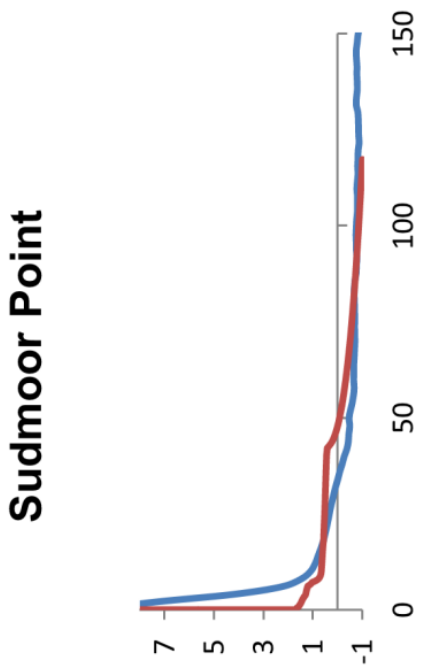

(w) ио!ฺе^әəコ

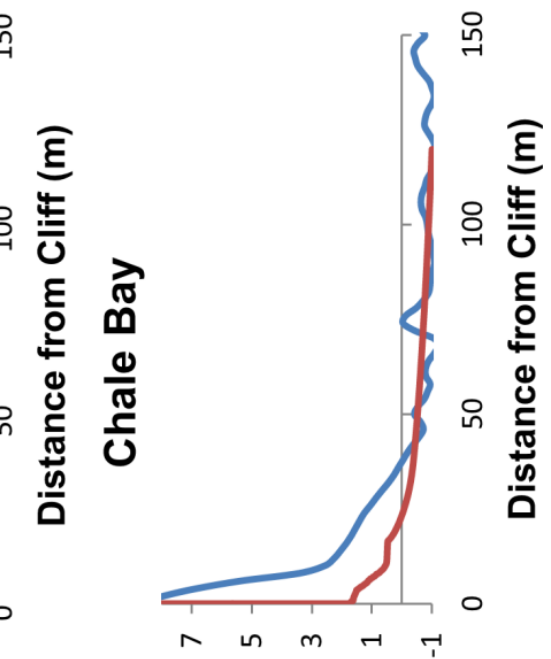

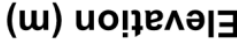

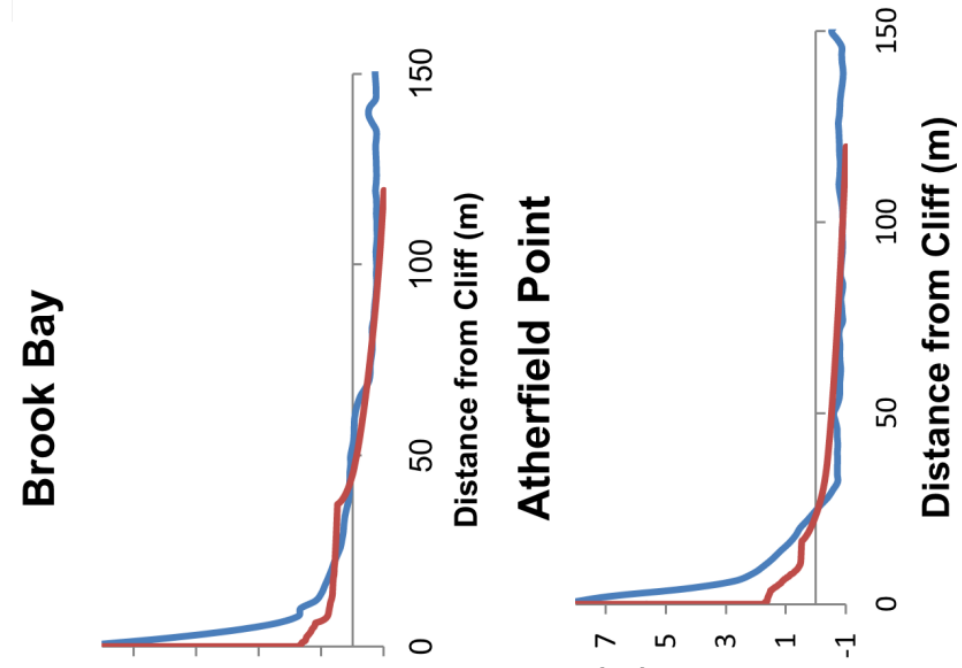

(u) ио!̣е^әㅋ

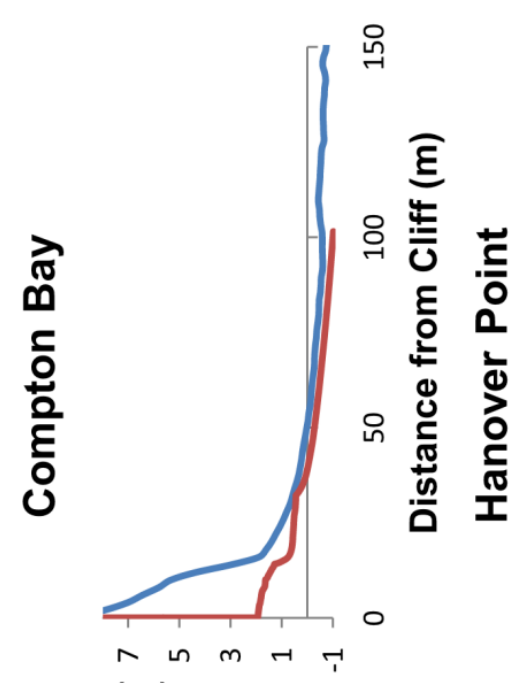

(u) นо!!e^әㅋ (u) ио!ฺеләㅋ

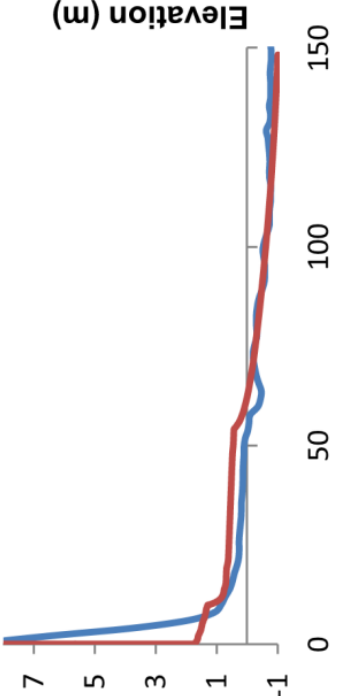

(u) ио!ฺеләәコ

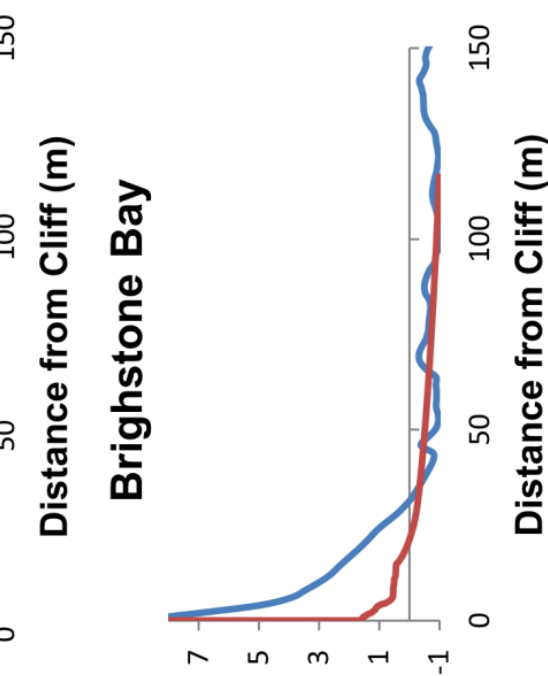

(u) บо!ฺอләээ

Figure 5. Model Validation, comparison of predicted and measured shore profiles 
Figure 5 also shows a vertical cliff face above MHWS within the modeled profiles. This is a relict feature of the 2D SCAPE model and can be discounted as the focus of the model is on the cliff toe and shore platform.

When considering the modeled results for the area further offshore (up to $1,000 \mathrm{~m}$ ) comparisons of modeled versus measured results (taken from C-MAP offshore bathymetry data) show some interesting trends. Figure 6 compares and contrasts data for Brook Bay. This highlights a generally good fit between data for the shore profile and offshore bathymetry of the site, with the angle of the slope fitting well to measured data. However, when focusing on the measured offshore bathymetry a significant ledge at approximately $-2 \mathrm{~m}$ OD can be observed which is not reflected within the SCAPE model results. This emergent feature can be attributed to a harder rock layer within the shore platform stratigraphy; such features can be observed along the study frontage at Lowest Astronomic Tide (LAT). The SCAPE model develops a smooth shore platform over time owing to the consideration of one constant value of rock strength in the cross shore. Consequently, the model cannot currently identify relationships between different hard rock layers in the cliff toe and shore platform and how these may form emergent features which interact with sea-level rise over time.

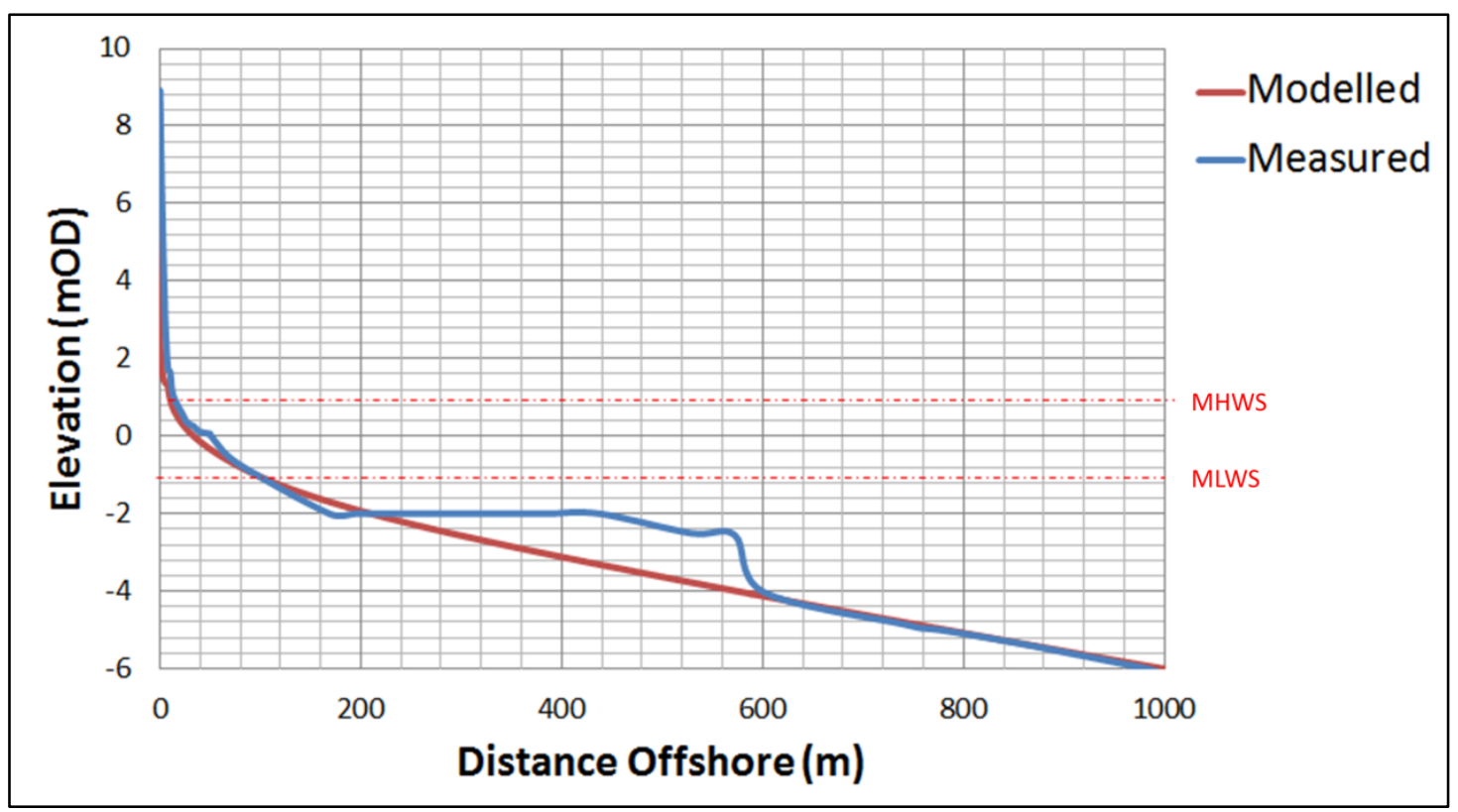

Figure 6. Model Validation, Brook Bay detailed comparison of predicted and measured shore and offshore profiles

\subsection{EVALUATION}

As an evaluation of the 2D model, we can conclude that the model generally describes the prevailing conditions sufficiently to replicate measured profiles along the study frontage. However, the validation of the model has also highlighted the importance of in-situ factors, especially varying rock strength across a profile. This is demonstrated by the varied geology of the study frontage (highlighted by Figure 4) which results in the range of emergent features and changing cliff behavior along the frontage. This is further supported by Stuiver (2010) who concluded that the most important terrestrial influence on recession rates is geology. This highlights some key questions to direct model development:

1. How to develop the rock strength calibration parameter for more complex cliff systems?

2. How will cross shore variations in rock strength influence results?

3. Is the mesoscale SCAPE assumption that coastal processes drive retreat appropriate for this frontage?

\subsection{Development of the Rock Strength Parameter}

As previously discussed, rock strength is currently only considered as a calibration parameter. Furthermore its treatment within this parameter is not exclusive, it is a hybrid parameter developed to represent material strength along with some other hydrodynamic constants, as described in Kamphuis (1987). Whilst this may be sufficient as a description of rock strength for simple cliff systems of 
relatively homogenous geology (i.e. north east Norfolk) it is insufficient to accurately describe more complex systems of varied geology. To adequately understand and simulate the cliff system, the representation of rock strength should be related to actual site conditions; otherwise the fixing of the model against past conditions may be flawed when looking at future rates. Independent research to develop this parameter has been undertaken by Castedo et al (2012) to separate out the calibration parameter into an individual rock strength value (uniaxial compressive strength, $\mathrm{kPa}$ ) along with a separate calibration parameter to represent the other hydrodynamic constants. The development of the rock strength parameter will become increasingly important within the application of the quasi-3D model where interactions of the cliff face with beach sediment and longshore transport become increasingly important.

\subsection{Cross Shore Variations in Rock Strength}

Validation of the 2D profiles (Figures 5 and 6) has also highlighted the limitations of the model only considering one value of rock strength for each cross shore profile. As a result the model cannot currently consider the development of emergent features due to harder rock layers within the shore platform and cliff toe. This poses an important question, particularly considering how these stronger stratigraphic units may interact with sea level rise over time and future land use management. For example, along the study frontage it is hypothesized that the discrete headlands have shifted spatially over human timescales. This is a result of the positioning and dip and strike of stronger stratigraphic units outcropping in the intertidal zone that cause an increase in shore platform elevation. The importance of variations in lithology as a control on the style and extent of landslides along the frontage is also highlighted by Jenkins et al (2011).

\subsection{Testing the Validity of SCAPE's Mesoscale Assumption and Identifying Terrestrial Drivers}

Finally, considering the SCAPE mesoscale assumption (that coastal processes are the key driver of cliff recession), if this were accurate a perfect linear relationship between cliff base and cliff top retreat would be expected. However, when plotted against each other ${ }^{4}$ Figure 7 demonstrates that, whilst the results are generally clustered around the 1:1 line, there is some significant scatter with an $r^{2}$ value of 0.21. Root Mean Square Errors (RMSE) for the entire frontage are approximately $31.37 \mathrm{~m}$. However, if we focus on some of the more specific landslide complexes RMSE are significantly larger, for example $51.83 \mathrm{~m}$ at Compton Farm landslide. This implies the influence of other in-situ terrestrial processes acting at the site and subsequently contests the mesoscale assumption.

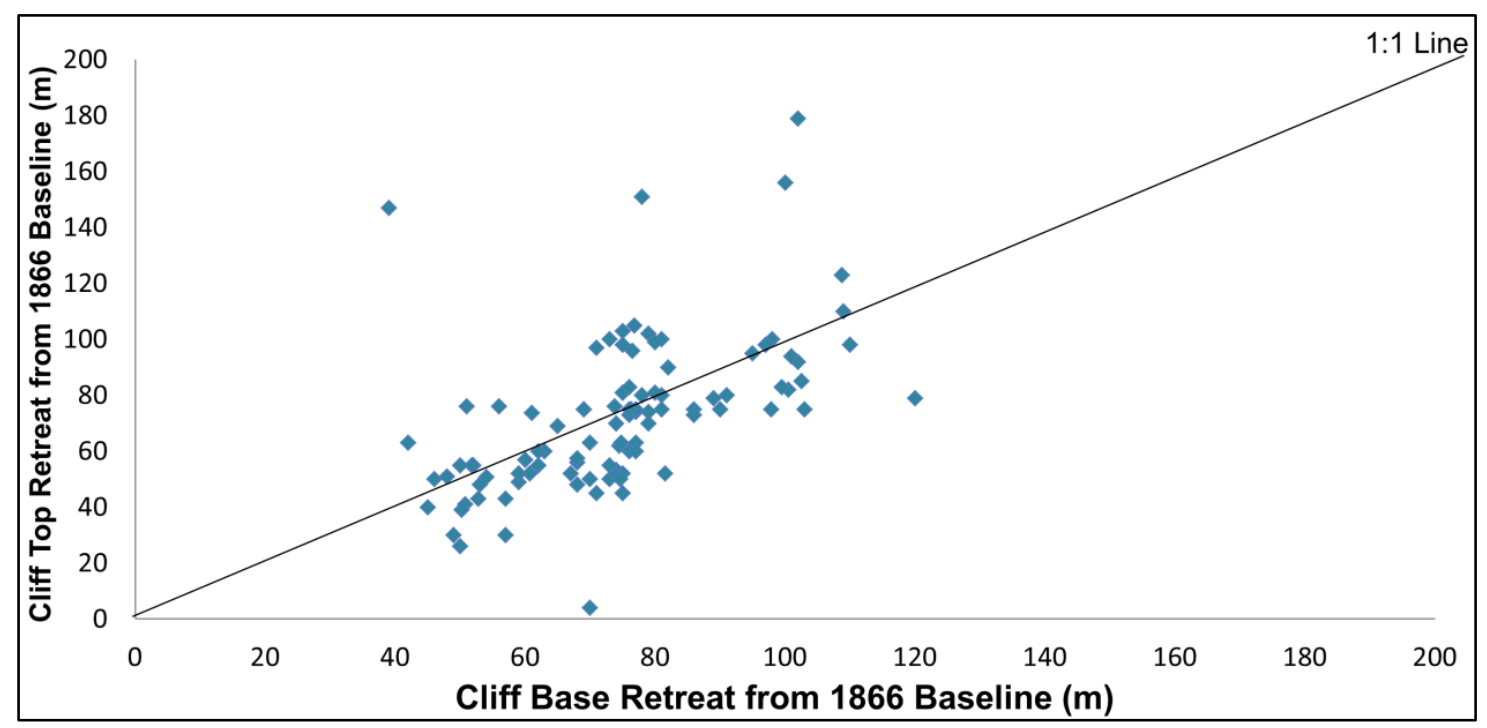

Figure 7. Measured cliff top versus cliff toe retreat across the study frontage based on DSAS Analysis (18662008)

${ }^{4}$ For points every $150 \mathrm{~m}$ along the study frontage using the DSAS for the range of historic maps and aerial photographs available for the frontage between 1866-2008 
An enhanced understanding of the cliff top position in relation to the cliff base is particularly important for the purpose of land-use planning and risk management. This emphasizes the need to determine the key driving terrestrial processes in the mesoscale and to establish the most appropriate method to describe them within a reduced complexity, process-based model such as SCAPE (i.e. process-based or empirical). To facilitate this understanding a comprehensive literature review of the range of systems and associated factors within the soft cliff recession process has been undertaken, as summarized in Table 5. This table shows the complexity of the recession process which is further exacerbated by interactions between these various factors and other associated parameters not listed. For example, the exposure of the cliff toe to waves is related to offshore wave heights (driven by wind and storm events), inshore wave transformation to breaking (related to bathymetry and shore platform characteristics) and wave run-up (dictated by beach characteristics).

\begin{tabular}{|c|c|c|c|}
\hline System & Role/Description & Factors & $\begin{array}{l}\text { Included in } \\
\text { SCAPE? }\end{array}$ \\
\hline $\begin{array}{l}\text { Geotechnical, } \\
\text { Geological \& } \\
\text { Hydro-geological }\end{array}$ & $\begin{array}{l}\text { The internal controls of the } \\
\text { cliff system which ultimately } \\
\text { determine its shear } \\
\text { strength. }\end{array}$ & $\begin{array}{l}\text { - Geology, lithology \& structure } \\
\text { - Cliff geometry (slope \& height) } \\
\text { - Strain softening \& progressive failure } \\
\text { - Groundwater \& pore water pressure } \\
\text { - Slope Stability and Mass Movements }\end{array}$ & $\begin{array}{l}5 \\
\gamma^{5} \\
x \\
x \\
x\end{array}$ \\
\hline Sub-Aerial & $\begin{array}{l}\text { Processes acting under the } \\
\text { atmosphere on the earth's } \\
\text { surface. }\end{array}$ & $\begin{array}{l}\text { - Slope vegetation } \\
\text { - Weathering (physical, chemical \& } \\
\text { biological) }\end{array}$ & $\begin{array}{l}X \\
X\end{array}$ \\
\hline Coastal and Marine & $\begin{array}{l}\text { Exposure of the cliff system } \\
\text { to driving coastal forces }\end{array}$ & $\begin{array}{l}\text { - Wave exposure } \\
\text { - Shore platform protective capacity } \\
\text { - Beach protective capacity } \\
\text { - Delivery of Talus material to cliff toe }\end{array}$ & $\begin{array}{l} \\
\checkmark \\
\checkmark \\
r\end{array}$ \\
\hline $\begin{array}{l}\text { Meteorological and } \\
\text { Climatic }\end{array}$ & $\begin{array}{l}\text { Atmospheric drivers and } \\
\text { potential changes to the } \\
\text { system as a result of } \\
\text { climate change. }\end{array}$ & $\begin{array}{l}\text { - Rainfall } \\
\text { - Tidal levels \& sea-level rise } \\
\text {-Storms }\end{array}$ & $\begin{array}{l}x \\
r \\
r\end{array}$ \\
\hline Human & $\begin{array}{l}\text { Anthropogenic intervention } \\
\text { of the cliff system }\end{array}$ & $\begin{array}{l}\text { - Engineering structure at cliff toe } \\
\text { - Slope stabilization } \\
\text { - Artificial drainage }\end{array}$ & $\begin{array}{l}r \\
x \\
x\end{array}$ \\
\hline
\end{tabular}

By comparing and contrasting Table 5 to the SCAPE process map (Figure 1) the parameters and processes considered within the existing SCAPE model and those omitted can be identified (as outlined in the final column). This highlights the comprehensive coastal system which has been developed within SCAPE considering a range of literature (Kamphuis, 1987, Nairn and Southgate, 1993b, Nairn and Southgate, 1993a, Skafel, 1995, Ferreira et al., 2000, Trenhaile, 2000) which provides a sound foundation for model development. However, Table 5 also demonstrates that the model does not consider a range of geotechnical and sub-aerial processes.

It can be noted that SCAPE is a deterministic model which does not take into consideration the influence of other climatic controls such as rainfall, as recognized by Dawson et al (2009). Considering the need to understand the impacts of climate change on the recession process, this factor can be identified as a key control on the terrestrial system which influences groundwater levels, pore water pressures within the cliff and in turn overall slope stability. Furthermore, the importance of rainfall within the cliff recession process has been highlighted by a range of studies (Ibsen and Brunsden, 1993, Clark et al., 1995, Brunsden and Chandler, 1996). However, the difficultly in establishing strong correlations between this factor and cliff recession is also recognized and this highlights the difficulty in attempting to incorporate such relationships within process-based models.

To further understand the interactions between the range of systems and associated factors an integrated and holistic conceptual model of soft cliff recession is required. This will assist in determination of the most appropriate method for incorporation of terrestrial processes within the SCAPE model.

\footnotetext{
${ }^{5}$ Description limited to material strength calibration parameter within the SCAPE model.

${ }^{6}$ Only considered within quasi-3D SCAPE model.
} 


\subsection{CONCLUSIONS AND FURTHER WORK}

An evaluation of the SCAPE model's ability to replicate present day shore profiles of varying cliff behavioral units (in comparison to those previously modeled) has highlighted the importance of vertical variation of rock strength within the cliff system. There is also a need to understand the influence of rainfall on the terrestrial system considering the impacts of climate change. Bearing in mind that the model is dependent on historic conditions as means of calibration and validation, it is particularly important that these factors are adequately described before action is taken to understand the future rates of soft rock cliff retreat. Furthermore, it is important that these factors are effectively represented to translate the cliff toe to an accurate and reliable cliff top position considering that cliff base projections are of little practical use.

In response to the key questions raised within the model evaluation, the further work within this project will firstly be to refine the rock strength parameter within the 2D SCAPE model to consider rock strength independently of calibration and to update preliminary model inputs. The 2D model can then be extended to consider the role of varying rock strength values in the vertical, which will enable interactions between harder stratigraphic units and sea-level rise to be investigated. These refinements can then be incorporated within the quasi-3D scape model before moving on to evaluate its performance considering the ability of the model to simulate known, varying rates of cliff recession and emergent features (long-shore and cross-shore) along the frontage. Upon evaluation it is anticipated that further methods to improve cliff top projections and responses to climate change can be identified.

Upon development of the refined SCAPE model it can be applied to the IoW study frontage to determine future cliff top behavior with respect to climate change. It is envisaged that this will feed in to the next generation SMP for the frontage to inform future coastal management policies and land-use planning through the identification of risk envelopes. The model will also be available for similar applications at other complex, soft rock cliff frontages.

\subsection{ACKNOWLEDGMENTS}

This work has been made possible through the Engineering and Physical Science Research Council (EPSRC) Doctoral Training Grant. The authors would also like to thank the Channel Coastal Observatory for data.

\subsection{REFERENCES}

Brampton, A.H., Evans, C.D.R. \& Velegrakis, A.F. 1998. Seabed Sediment Mobility West of the Isle of Wight. Project Report 65. London: CIRIA.

Brooks, S.M. \& Spencer, T. 2012. Shoreline Retreat and Sediment Release in Response to Accelerating Sea-Level Rise: Measuring and Modelling Cliffline Dynamics on the Suffolk Coast, UK. Global and Planetary Change, 80-81, 165-179.

Brown, I., Jude, S., Koukoulas, S., Nicholls, R., Dickson, M. \& Walkden, M. 2006. Dynamic Simulation and Visualisation of Coastal Erosion. Computers Environment and Urban Systems, 30, 840860 .

Brunsden, D. \& Chandler, J.H. 1996. Development of an Episodic Landform Change Model Base Upon the Black Ven Mudslide, 1946-1995. In: Anderson, M.G. \& Brooks, S.M. (eds.) Advances in Hillslope Processes 2. Wiley.

Bruun, P. 1954. Coast Erosion and Development of Beach Profiles. Technical Memorandum no. 44. Beach Erosion Board, US Army Corps of Engineers.

Castedo, R., Paredes, C., Murphy, W. \& Lawrence, J. 2012. Process-Response Coastal Bluff Recession Model: Application to Holderness Coast (UK). Poster. International Conference on Coastal Engineering. Santander, Spain.

Channel Coastal Observatory 2010. Annual Wave Report: Milford Directional Waverider Buoy. Southampton: Channel Coastal Observatory.

Clark, A.R., Moore, R. \& Mcinnes, R. 1995. Landslide Response and Management: Blackgang, Isle of Wight. Proceedings of the 30th MAFF Conference of River and Coastal Engineers.

Dawson, R.J., Dickson, M.E., Nicholls, R.J., Hall, J.W., Walkden, M.J.A., Stansby, P.K., Mokrech, M., Richards, J., Zhou, J., Milligan, J., Jordan, A., Pearson, S., Rees, J., Bates, P.D., Koukoulas, S. \& Watkinson, A.R. 2009. Integrated Analysis of Risks of Coastal Flooding and Cliff Erosion Under Scenarios of Long Term Change. Climatic Change, 95, 249-288.

Dickson, M., Walkden, M. \& Hall, J. 2007. Systemic Impacts of Climate Change on an Eroding Coastal Region over the Twenty-First Century. Climatic Change, 84, 141-166. 
Eurosion 2004. Living with coastal erosion in Europe: sediment and space for sustainability: major findings and policy recommendations of the EUROSION project. European Commission, Directorate General Environment.

Ferreira, O., Ciavola, P., Taborda, R., Bairros, M. \& Dias, J.A. 2000. Sediment Mixing Depth Determination for Steep and Gentle Foreshores. Journal of Coastal Research, 16, 830-839.

Haigh, I.D., Nicholls, R. \& Wells, N. 2011. Rising Sea-Levels in the English Channel 1900 to 2100. Proceedings of ICE Maritime Engineering, 164.

Hall, J.W., Meadowcroft, I.C., Lee, E.M. \& Van Gelder, P. 2002. Stochastic Simulation of Episodic Soft Coastal Cliff Recession. Coastal Engineering, 46, 159-174.

Ibsen, M.L. \& Brunsden, D. 1993. The Spatial and Temporal Distributions of Landslides on the South Coast of Britain. In: Casale, R., Fantechi, R. \& Flageollet, J.C. (eds.) Temporal Occurence and Forecasting of Landslides in the European Community.

Insole, A., Daley, B. \& Gale, A. 1998. The Isle of Wight: Geologists' Association Guide No. 60, London, UK, Geologists Association.

Isle of Wight Council 2010. Committee Report: Military Road (A3055) - Options. Report of Cabinet Member for Environment and Transport. Isle of Wight Council.

Isle of Wight Council \& Haskoning, R. 1997. Isle of Wight Shoreline Management Plan 2. Isle of Wight: Directorate of Economy and the Environment.

Isle of Wight Council \& Royal Haskoning 2010. Isle of Wight Shoreline Management Plan 2. Appendix C: Baseline Process Understanding. Isle of Wight: Directorate of Economy and the Environment.

Jenkins, G.J., Foster, C. \& Hopson, P.M. Year. Geology as a Control on Landslides on the Isle of Wight: An Overview. In: Proceedings of the Geologists' Association, 2011.

Kamphuis, J. 1987. Recession Rates of Glacial Till Bluffs. Journal of Waterway, Port, Coast and Ocen Engineering, 113, 13.

Kamphuis, J. 2000. Introduction to Coastal Engineering and Management, Singapore, World Scientific.

Lee, E.M. \& Clark, A.R. 2002. Investigation and Management of Soft Rock Cliffs, London, Thomas Telford Publishing.

Leyland, J. 2009. Modelling the Holocene Evolution of Coastal Gullies on the Isle of Wight. PhD Thesis. University of Southampton.

Leyland, J. \& Darby, S.E. 2008. An Empirical-Conceptual Gully Evolution Model for Channeled Sea Cliffs. Geomorphology, 102, 413-434.

Linham, M.M. \& Nicholls, R.J. 2010. Technologies for Climate Change Adaptation: Coastal Erosion and Flooding, New Delhi, India, United Nations Environment Program, Global Environment Facility.

Meadowcroft, I.C., Hall, J.W., Lee, E.M. \& Milheiro-Oliveira, P. 1999. Coastal Cliff Recession: Development and Application of Prediction Methods. HR Wallingford Report SR549.

Nairn, R.B. \& Southgate, H.N. 1993a. Deterministic Profile Modelling of Nearshore Processes. Part 1: Waves and Currents. Coastal Engineering, 19, 27-56.

Nairn, R.B. \& Southgate, H.N. 1993b. Deterministic Profile Modelling of Nearshore Processes. Part 2: Sediment Transport and Beach Profile Development. Coastal Engineering, 19, 57-96.

Pye, K. \& French, P.W. 1993. Targets for Coastal Habitat Re-creation. English Nature Science Series. Peterborough: English Nature

Quinn, J.D., Rosser, N.J., Murphy, W. \& Lawrence, J.A. 2010. Identifying the Behavioural Characteristics of Clay Cliffs using Intensive Monitoring and Geotechnical Numerical Modelling. Geomorphology, 120, 107-122.

Scopac 2004. Sediment Transport Study. Available from: http://www.scopac.org.uk/sedimenttransport.htm.

Skafel, M.G. 1995. Laboratory Measurement of Nearshore Velocities and Erosion of Cohesive Sediment (Till) Shorelines. Coastal Engineering, 24, 343-349.

Soares, L. 1993. Determination of the Coherence Grade of Soft Rocks. Geotechnical Engineering of Hard Soils - Soft Rocks, 1, 281-286.

Stuiver, C. 2010. Coastal Erosion on the South West Coast of the Isle of Wight. Unpublished Masters Thesis. Southampton: University of Southampton.

Sunamura, T. 1992. Geomorphology of Rocky Coasts, Chichester, UK, John Wiley.

Thieler, E.R., Himmelstoss, E.A., Zichichi, J.L. \& Ergul, A. 2009. Digital Shoreline Analysis System (DSAS) Version 4.0 - An ArcGIS Extension for Calculating Shoreline Change. US Geological Survey Open-File Report 2008-1278. 
Trenhaile, A.S. 2000. Modelling the Development of Wave-Cut Shore Platforms. Marine Geology, 14. Trenhaile, A.S. 2004. Modelling the Accumulation and Dynamics of Beaches on Shore Platforms. Marine Geology, 206, 55-72.

Trenhaile, A.S. 2009. Modeling the Erosion of Cohesive Clay Coasts. Coastal Engineering, 56, 59-72. Walkden, M. \& Dickson, M. 2008. Equilibrium Erosion of Soft Rock Shores with a Shallow or Absent Beach under Increased Sea Level Rise. Marine Geology, 251, 75-84.

Walkden, M. \& Hall, J. 2011. A Mesoscale Predictive Model of the Evolution and Management of a Soft Rock Coast. Journal of Coastal Research, 27, 529-543.

Walkden, M.J.A. \& Hall, J.W. 2005. A predictive Mesoscale model of the erosion and profile development of soft rock shores. Coastal Engineering, 52, 535-563. 